\title{
Actual laser removal of black soiling crust from siliceous sandstone by high pulse repetition rate equipment: effects on surface morphology
}

\author{
M.A. Iglesias-Campos ${ }^{\mathrm{a}, \mathrm{b}} \bowtie$, J.L. Prada-Pérez ${ }^{\mathrm{b}}$ \\ a. Secció de Conservació-Restauració. Facultat de Belles Arts, Universitat de Barcelona, (Barcelona, Spain) \\ b. GRAPAC/CETEC-patrimoni, Universitat Autònoma de Barcelona-Institut Químic de Sarrià, (Barcelona, Spain) \\ \manuel.iglesias@ub.edu
}

\begin{abstract}
This research project studies the role of pulse repetition rate in laser removal of black soiling crust from siliceous sandstone, and specifically, how laser fluence correlates with high pulse repetition rates in cleaning practice. The aim is to define practical cleaning processes and determine simple techniques for evaluation based on end-users' perspective (restorers). Spot and surface tests were made using a Q-switched Nd:YAG laser system with a wide range of pulse repetition rates $(5-200 \mathrm{~Hz})$, systematically analysed and compared by macrophotography, portable microscope, stereomicroscope with 3D visualizing and area roughness measurements, SEM imaging and spectrophotometry. The results allow the conclusion that for operation under high pulse repetition rates the average of total energy applied per spot on a treated surface should be attendant upon fluence values in order to provide a systematic and accurate description of an actual laser cleaning intervention.
\end{abstract}

KEYWORDS: Sandstone; Laser Cleaning; Image Analysis; Roughness; Spectrophotometry

Citation/Citar como: Iglesias-Campos, M.A.; Prada-Pérez, J.L. (2016) Actual laser removal of black soiling crust from siliceous sandstone by high pulse repetition rate equipment: effects on surface morphology. Mater. Construcc. 66 [321], e078. http://dx.doi.org/10.3989/mc.2016.02215.

RESUMEN: Limpieza real de costra negra de contaminación en arenisca silícea con láser de elevado pulso de repetición: efectos morfológicos en la superficie. En este trabajo se estudia el papel de la frecuencia de repetición en la limpieza láser de costras de contaminación sobre una arenisca silícea, y concretamente, como se relaciona fluencia y frecuencias elevadas en una limpieza real. Se pretende definir un procedimiento práctico de limpieza y determinar técnicas sencillas de evaluación desde el punto de vista de los usuarios finales (restauradores). Para el estudio se realizaron diferentes ensayos en spot y en superficie mediante un equipo Q-switched Nd:YAG con un amplio rango de frecuencias $(5-200 \mathrm{~Hz})$, que se analizaron y compararon sistemáticamente mediante macrofotografía, microscopio portátil, estereomicroscopio con visualización 3D y mediciones de rugosidad en área, imágenes SEM y espectrofotometría. Los resultados permiten proponer que, al trabajar con altas frecuencias, la media de la energía total depositada por spot en la superficie debería acompañar los valores de fluencia para describir y comprender mejor una limpieza real con láser.

PALABRAS CLAVE: Arenisca; Limpieza Láser; Análisis de imágenes; Rugosidad; Espectrofotometría

Copyright: (C) 2016 CSIC. This is an open-access article distributed under the terms of the Creative Commons Attribution-Non Commercial (by-nc) Spain 3.0 License. 


\section{INTRODUCTION}

The development of laser cleaning from its beginnings, and mainly since the late 1990s, has led to its frequent use on several architectural heritage projects. The technique is referred to in general publications about stone conservation $(1,2)$, in specific monographs $(3,4)$, in a large number of research and practical applications published in the proceedings of the International Conferences of LACONA (Lasers in the Conservation of Artworks), and in papers where laser technique was favourably compared with traditional cleaning methods, being more effective and safer (5-12). Also, the general standards or recommendations referred to in building-cleaning literature may include this technique (13-15), but when it is mentioned only general criteria are described. However there is a specific standard establishing a detailed procedure to assess and define the treatment (16).

The literature provides essential information in order to set parameters on laser application. According to publications, the main parameters controlling the technique are wavelength, pulse duration (characteristics of the equipment which the restorer cannot normally modify), fluence or energy density, repetition rate and whether the treatment is performed in wet or dry conditions (parameters adjustable by the restorer). Most of the parameters described focus on fluence, often accompanied by technical data of laser equipment which restricts knowledge of planning, treatment performance and extrapolation of data for similar situations.

For this purpose it is fundamental to understand and consider all practical issues encountered in an actual laser cleaning intervention. In practice, upon laser cleaning, restorer directs laser beam manually onto the surface with a hand-held device. The cleaning is performed from the repeated incidence of laser beam on soiling deposits for a period of time determined by the restorer's observation in order to achieve the required cleaning level. In this process, dependent on several factors (material, soiling, equipment and application), either a satisfactory result can be reached or the substrate can be altered. Damage, if it occurs, is generally manifested as material loss and/or partial mineral fusion (related to photothermal and photomechanical mechanisms of the technique) and colour changes (related to migration of yellow polar crust compounds, chemical mineral alteration or uneven crust removal) (17-19).

These studies have been conducted with low pulse repetition rate equipment; however, laser systems of high repetition rate $(200 \mathrm{~Hz}$ or higher) have recently been introduced into the conservation market and practice, and a systematic study of their cleaning procedure and use, in comparison to the usual low repetition ones (lower than $30 \mathrm{~Hz}$ ), has not been established yet.
With both low and high repetition rate equipment, laser cleaning depends on the restorer's manually operated laser beam movement and on spot overlapping. It therefore seems necessary to study the spot as a starting point to understand the cleaning process.

Through different spot and surface tests, this paper studies how laser fluence correlates with high frequency rates and average of total energy applied per spot on the basis of existing practices. Results and conclusions are based on the experience and perspective of restorers. A proposal is made for an applied methodology to report previous tests and decisions during an actual intervention with these laser systems. It systematizes useful procedures for end-users and determines simple techniques for a preliminary evaluation highlighting potential surface alterations because they are easily interpretable by the restorer.

\section{MATERIALS AND METHODS}

Tests were carried out on a column fragment from a late 19th century building in the Eixample, Barcelona, Spain. The fragment was located on the upper floor, approximately $20 \mathrm{~m}$ high, sheltered by a cornice at the SW façade. A preliminary study of the material (siliceous sandstone) and its alteration (black soiling crust) was conducted and the data obtained were used to direct the trials. Even though it is a studied stone material $(20,21)$, both material and alteration were analysed by stereomicroscope and SEM-EDS (Zeiss EVO ${ }^{\circledR}$ MA10 scanning electron microscope).

Spot and surface cleaning tests in dry conditions were made in laboratory simulating in situ treatment. The equipment used was a Q-switched $\mathrm{Nd}$ :YAG diode pumped laser at $1064 \mathrm{~nm}$, pulse duration 5-10 ns, energy 2-12 mJ adjustable, repetition rate $5-200 \mathrm{~Hz}$ adjustable, average power $2.1 \mathrm{~W}$, fibre transmitted, hand-held device and divergent focus optics. This equipment, unlike common laser systems, has a low pulse energy but higher repetition rate and it has been used in some studies (22-24). The use of high repetition rate laser systems in building materials is reported in few cases. However, there are commercial equipments used in some interventions $(25,26)$ and in recent studies $(27)$.

Initially, to evaluate spot and surface tests, mainly crust removal and potential surface alteration, each sample was analysed by macrophotography and portable microscope (PCE-MM200 with $\times 10-200$ adjustable), considered as in situ evaluation. Surface tests were also analysed by SEM. Subsequently, surface roughness and colour measurements were taken to evaluate cleaning tests (28).

Primary profile of spot and surface tests were evaluated by a Leica M165C stereomicroscope with software Leica Stereo-Explorer 3D visualizing and 
surface roughness measurements. Additionally, surface test images at $\times 20$ were taken and mean values for the area field roughness parameters (29) were obtained from three different sub-areas of $9 \mathrm{~mm}^{2}$ filtered with a $600 \mu \mathrm{m}$ cut-off (1/5 of profile evaluation length). For control purposes, soiled surfaces were measured too. However, because soiling always fills up surface valleys reducing original roughness, it was not considered a significant data item of the original surface. Sa (arithmetic mean height), $\mathrm{Sq}$ (root mean square height) and $\mathrm{S} 10 \mathrm{z}$ (maximum height of 10 peaks/valleys) parameters were selected to compare area roughness. Nevertheless, as $\mathrm{Sa}$ and Sq could be identical even if surfaces were different, volume parameters of Vmp (peak material volume), Vvv (valley void volume), Vmc (core material volume) and $\mathrm{Vvc}$ (core void volume) were included to clarify evaluation.

As an indicator of cleaning degree, CIELab measurements were conducted before and after treatment with a spectrophotometer (Konica Minolta CM-2600d). Three measurements were taken of each soiled and cleaned surface test using a target mask of $\varnothing 3 \mathrm{~mm}$, specular component included, illuminant D65 and $10^{\circ}$ observer. The total colour change $\Delta \mathrm{E}^{*}$ was calculated according to CIELab

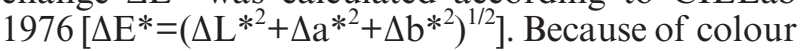
in rock fracture would be an excessive cleaning, the reference value for evaluation was taken from comparison between test.

These analytical techniques present data easily interpretable by the restorer, providing useful information to distinguish cleaning effects on stone surface and to take decisions in an actual intervention.

\subsection{Stone and black crust}

The stone is Montjuïc siliceous sandstone, a commonly used building material in Barcelona throughout its history. The column fragment corresponds to the grey lithology. This is a variety with a high content of quartz (80-90\% volume), slight amount of feldspar and mica $(<10 \%$ volume), minor degree of rock fragments (schist, quartzite, etc.; $\leq 0.5-2 \%$ volume) and porosity between $18-20 \%$. Mineral grains are equigranular with subangular forms (ranging from 150 to $300 \mu \mathrm{m}$ ), cement is siliceous and texture relatively homogeneous, quite compact. Surface finishing is smooth (honed finishing), being understood in this case as microrough due to the grain size.

Stone surface was well preserved although it had a black soiling crust ranging from 85 to $180 \mu \mathrm{m}$. The crust does not seem to affect the substrate petrographic texture at any place (Figure 1). Its analysis by SEM-EDS shows residues of unburned carbon and eolic silica particles with a slightly compact texture.

The most influential of these properties on laser cleaning are mineralogical composition, colour, porosity and texture. Colour difference between soiling (black) and stone (light-grey) seems to make treatment feasible. Porosity, texture and surface finishing could make the cleaning process more difficult increasing the possibility of substrate laser absorption. Some material loss and/or colour changes could be provoked owing to sandstone mineralogical composition $(3,8,30-34)$ as in other siliceous stones (35).

\subsection{Laser tests}

At the outset, it was decided to follow the standard (16). Briefly described, it proposes spot tests (smaller than $5 \mathrm{~mm}^{2}$ ), keeping constant distance, repetition rate $(5$ or $10 \mathrm{~Hz})$ and time (not inferior to $10 \mathrm{~s}$ ), increasing fluence.

Analysing technical characteristics of the equipment used, it was decided to adapt the standard to the specific situation because design and settings of this laser system are different from the common equipment. The spot diameter will always be smaller because its focal distance, approximately $3 \mathrm{~cm}$, generates spots ranging from 1 to $1.5 \mathrm{~mm}^{2}$. Due to defocusing, it does not allow a significant increase/decrease of spot area without considerable loss of effectiveness and otherwise the variation of energy density leads to non-homogeneous results as in similar systems (27). Its reduced power means that low energies
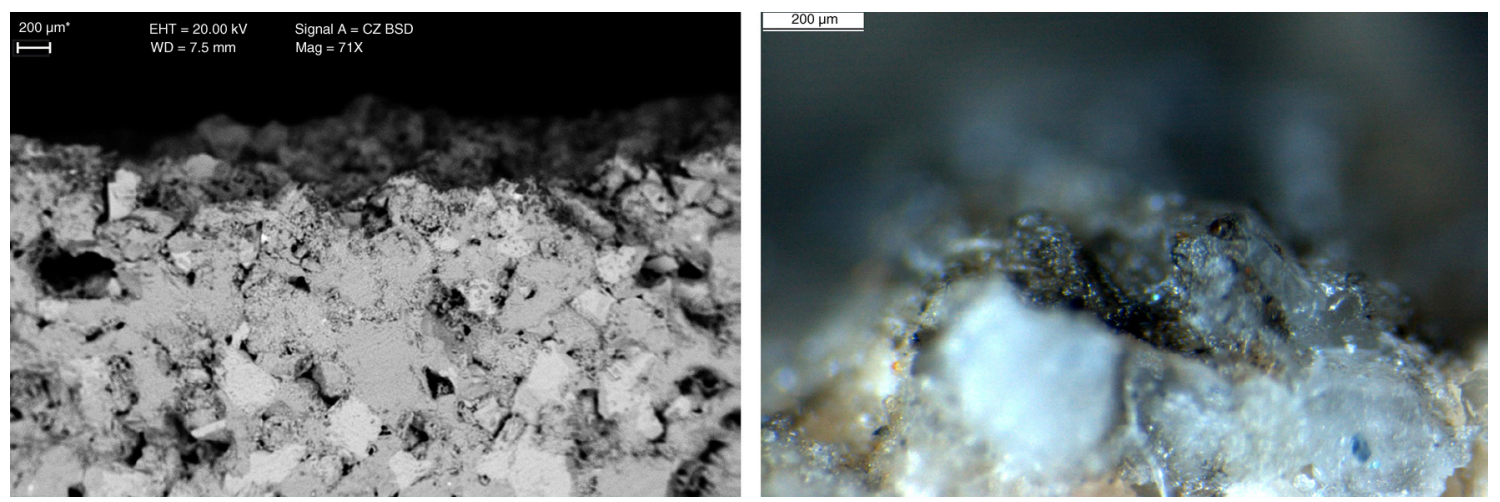

FIgURE 1. Cross section: stone and crust SEM-BSE image (left) and stone and crust stereomicroscope image (right). Scale $200 \mu \mathrm{m}$. 
do not have a significant effect on thick black soiling crusts and previous tests using this equipment determined that energies less than 8-10 mJ make cleaning process very slow and economically unfeasible (22-24). However, its greater repetition rate (allowing up to $200 \mathrm{~Hz}$ ) appears to increase cleaning rate.

In addition, mainly due to high repetition rate, consideration was also given to which defining parameter, besides fluence, would be used to define the treatment, particularly for surface tests. Owing to restorer's manually operated laser beam movement and to its overlapping during laser cleaning practice, it could be considered that numerical value of fluence may appear incomplete because it does not include spot movement during cleaning.

Fluence $(\mathrm{F})$ relates energy and area and expresses laser/matter interaction as pulse energy applied in a given area $\left[\mathrm{F}=\mathrm{E} / \mathrm{A}\right.$; expressed in $\left.\mathrm{J} / \mathrm{cm}^{2}\right](3,15,33)$. Another parameter independent of the equipment, and therefore only determining energy supplied to the material, is irradiance or average power by area $\left[\mathrm{I}=\mathrm{P}_{\mathrm{avg}} / \mathrm{A}\right.$; expressed in $\left.\mathrm{W} / \mathrm{cm}^{2}\right]$ where pulse duration is included (33). Both irradiance and fluence are values which inform about the energy applied by area and express laser/matter interaction but do not allow for the dynamic parameter of manual spot movement, evidently related to repetition rate, which is difficult to establish if not carried out by automated testing (and moreover, it would not be representative of an actual cleaning).

In this case, some authors $(23,24)$ suggest that, besides fluence, it is necessary to know the average of total energy applied per spot which could be calculated on the basis of the number of pulses required to achieve soiling ablation. Thus, if any alteration on the substrate is detected, the total energy under which it occurs could be determined. Accordingly, fluence gives the amount of energy per pulse in the irradiated area and, in order to determine the average of total energy per spot, it is necessary to know the number of pulses per spot in a given area (23). The average of total energy applied per spot $\left(\mathrm{E}_{\mathrm{avg}}\right)$ is calculated according to the repetition rate (f), the time in seconds to clean $1 \mathrm{~cm}^{2}(\mathrm{t})$, the spot irradiation area in $\mathrm{cm}^{2}(\mathrm{~A})$, and the energy per pulse (E) used in the tests $\left[E_{\text {avg }}=f \times t \times A \times E\right.$; expressed in $\left.J\right)$.

\subsection{Experimental}

From this theoretical approach and to establish comparatives, spot and surface tests in dry conditions were made keeping energy, time, distance and angle constant, only modifying repetition rate (in the available range of 5 to $200 \mathrm{~Hz}$ ). Energy was set at $10 \mathrm{~mJ}$ because previous tests with this equipment in similar situations have shown that lower energies have no cleaning effect or rather are costeffectively unviable in an actual intervention (2224). The hand-held deviced was fixed with a clamp to prevent movement affecting the results at $30 \mathrm{~mm}$, as the equipment focuses approximately at this distance, and $90^{\circ}$ angle, generating a spot diameter of $0.12 \mathrm{~cm}$ and an irradiated area of $0.0113 \mathrm{~cm}^{2}$. The column fragment was placed vertically to reproduce an actual wall cleaning. Fluence and average of total energy applied per spot were calculated.

Three spot tests (referred to as A, B, C) with each available repetition rate were carried out in dry conditions keeping energy, time, distance and angle constant and laser beam was guided directly onto the sample. In addition to fluence, repetition rate and time interval are reflected in the average of total energy per spot.

Surface tests in dry conditions were performed on small contiguous surfaces of $0.27 \mathrm{~cm}^{2}(0.9 \times 0.3 \mathrm{~cm})$ to reduce potential differences in bonding between crust/substrate and to include restorer's manual movement of laser beam without changes in distance and angle that could influence the results. Energy, distance and angle remained the same as in spot tests only modifying the available repetition rate. A reference rail was used to maintain distance and angle.

A fixed time interval was not set in order to allow the restorer to adjust the number of pulses according to characteristics of treated area. As the intention was to reproduce an actual cleaning, irradiation time can differ depending on immediate visual assessment and on the selected repetition rate. Treatment time for each surface test was recorded.

To provide reference of the initial situation, and related with an actual cleaning, surface tests were masked and every cleaned surface was covered after treatment in order to prevent visual comparisons that could influence the restorer, especially in treatment time.

Consequently, in this case, as well as fluence and repetition rate, the amount of cleaned area and irradiation time must also be taken into account (reflected in average of total energy per spot calculation).

\section{RESULTS AND DISCUSSION}

\subsection{Spot tests}

Fluence indicates that results do not reflect pulse repetition rate and that the average of total energy per spot is clearly related to repetition rate and treatment time (Table 1). All spots received the same fluence because energy and distance were constant but average of total energy per spot is different depending on repetition rate.

Spot analysis using portable microscope and 3D stereomicroscope with visualizing and surface roughness measurements show that morphologically the treated area in some cases is uneven (Figure 2). This difference additionally could increase due to the Gaussian distribution along the laser beam itself 
TABLE 1. Spot tests parameters and results

\begin{tabular}{|c|c|c|c|c|c|c|c|c|}
\hline \multirow[b]{2}{*}{ Spot test } & & \multicolumn{4}{|c|}{ Constant parameters } & \multicolumn{3}{|c|}{ Variable parameters } \\
\hline & & $\begin{array}{c}\text { Energy } \\
(\mathrm{mJ})\end{array}$ & $\begin{array}{l}\text { Spot } \\
\left(\mathrm{cm}^{2}\right)\end{array}$ & $\begin{array}{l}\text { Fluence } \\
\left(\mathrm{J} / \mathrm{cm}^{2}\right)\end{array}$ & $\begin{array}{c}\text { Time } \\
\text { (s) }\end{array}$ & $\begin{array}{l}\text { Repetition } \\
\text { rate }(\mathrm{Hz})\end{array}$ & $\begin{array}{c}\mathbf{E}_{\text {avg }} \\
\operatorname{spot}(\mathbf{J})\end{array}$ & Results \\
\hline \multirow[t]{3}{*}{ PL-M1 } & $\mathrm{A}$ & 10 & 0.0113 & 0.8849 & 10 & 5 & 0.50 & $\mathrm{D}$ \\
\hline & $\mathrm{B}$ & & & & & & & $\mathrm{D}$ \\
\hline & $\mathrm{C}$ & & & & & & & ND \\
\hline \multirow[t]{3}{*}{ PL-M2 } & A & 10 & 0.0113 & 0.8849 & 10 & 10 & 1 & $\mathrm{D}$ \\
\hline & B & & & & & & & $\mathrm{D}$ \\
\hline & $\mathrm{C}$ & & & & & & & ND \\
\hline \multirow[t]{3}{*}{ PL-M3 } & A & 10 & 0.0113 & 0.8849 & 10 & 50 & 5 & $\mathrm{D}$ \\
\hline & B & & & & & & & ND \\
\hline & $\mathrm{C}$ & & & & & & & $\mathrm{D}$ \\
\hline \multirow[t]{3}{*}{ PL-M4 } & A & 10 & 0.0113 & 0.8849 & 10 & 100 & 10 & ND \\
\hline & B & & & & & & & $\mathrm{D}$ \\
\hline & $\mathrm{C}$ & & & & & & & ND \\
\hline \multirow[t]{3}{*}{ PL-M5 } & A & 10 & 0.0113 & 0.8849 & 10 & 150 & 15 & ND \\
\hline & $\mathrm{B}$ & & & & & & & ND \\
\hline & $\mathrm{C}$ & & & & & & & $\mathrm{D}$ \\
\hline \multirow[t]{3}{*}{ PL-M6 } & A & 10 & 0.0113 & 0.8849 & 10 & 200 & 20 & $\mathrm{D}$ \\
\hline & B & & & & & & & $\mathrm{D}$ \\
\hline & $\mathrm{C}$ & & & & & & & ND \\
\hline
\end{tabular}

Legend: (ND) no damage, (D) material loss.
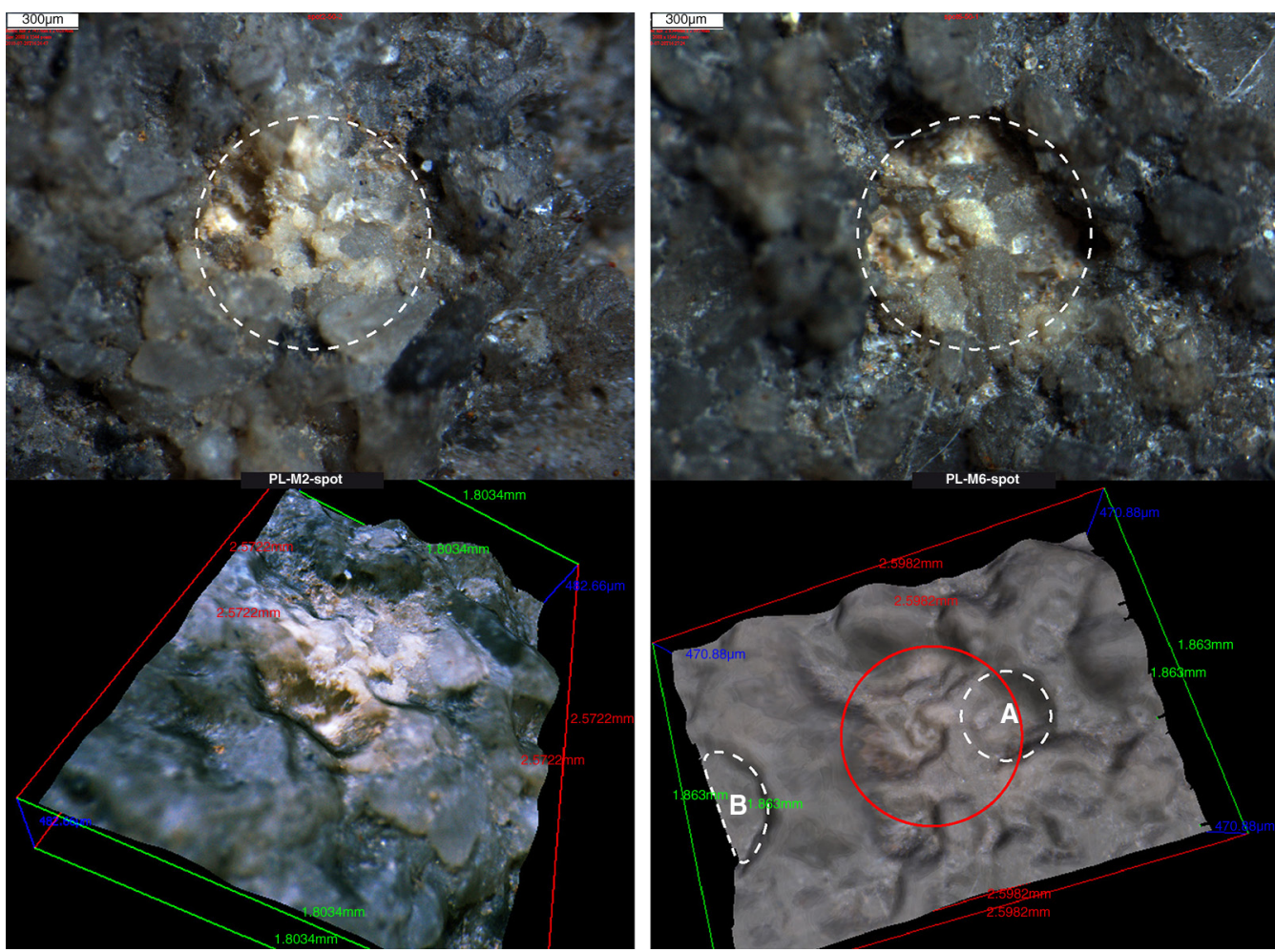

FIGURE 2. Spots (theoretical circumference in dotted circle) and spots surface topography: irregular spot shape and uneven spot cleaning (left) and regular spot shape (top right). Topography in uniform texture: theoretical spot (in red circle), depression by material loss in treated area $-\mathrm{A}-$ and similar depression in the untreated one - B - (bottom right). 3D stereomicroscope images. Scale $300 \mu \mathrm{m}$. 
that could provoke more intense peaks in the centre than at the periphery.

To confirm these deviations, theoretical circumference of spot test was superimposed on the images. It can be observed that laser beam disperses on the surface in some cases and the cleaning effect outside the theoretical spot, if it occurs, is less intense. As absorption capacity also depends on surface irregularities, the uneven microrough stone texture has a larger specific area and the reflected laser beam may have different interactions with minerals. Therefore the total area can absorb more energy on average (3).

In all spot tests a central area with a more intense cleaning effect (or damage) can occasionally be seen. Image analysis shows that if damage occurs, it corresponds with a very defined circular spot where energy density could have been more concentrated due to beam reflection depending on mineral grain orientation (3) (Figures 2, 3). Alteration is usually related to sandstone binding phases. According to most references on siliceous sandstones $(3,8,30-34)$ its origin can be found mainly in shock waves and photothermal and photomechanical effects affecting the most sensitive minerals. Fluence or average of total energy per spot cannot be linked with damage because there are spots both undamaged and damaged in the same spot test where repetition rate was maintained (Table 1). Heterogeneity of microroughness surface (grain morphology, orientation and size) seems to explain this behaviour.

Primary profile analysis failed to provide sufficient information for evaluation. Crust is removed but primary profiles do not clearly reflect it because the stone microroughness has similar, or even lower, peaks and valleys to those of the untreated area (Figure 3). Something similar is observed comparing uniform topography in texture. Although there is an important recess in the treated area, similar valleys appear in the untreated one making spot treatment interpretation difficult (Figure 2). Nevertheless, spot test analysis provides useful information about potential surface damage on a specific small area.

\subsection{Surface tests}

Fluence is the same as in spot tests because energy, distance and hence spot area were constant. However, the average of total energy per spot is different because it depends on repetition rate and restorer's manual laser beam movement during cleaning (reflected in treatment time). Differential value is the average of total energy per spot calculated from the number of pulses necessary to achieve soiling ablation in a specific area and time. It can be seen that
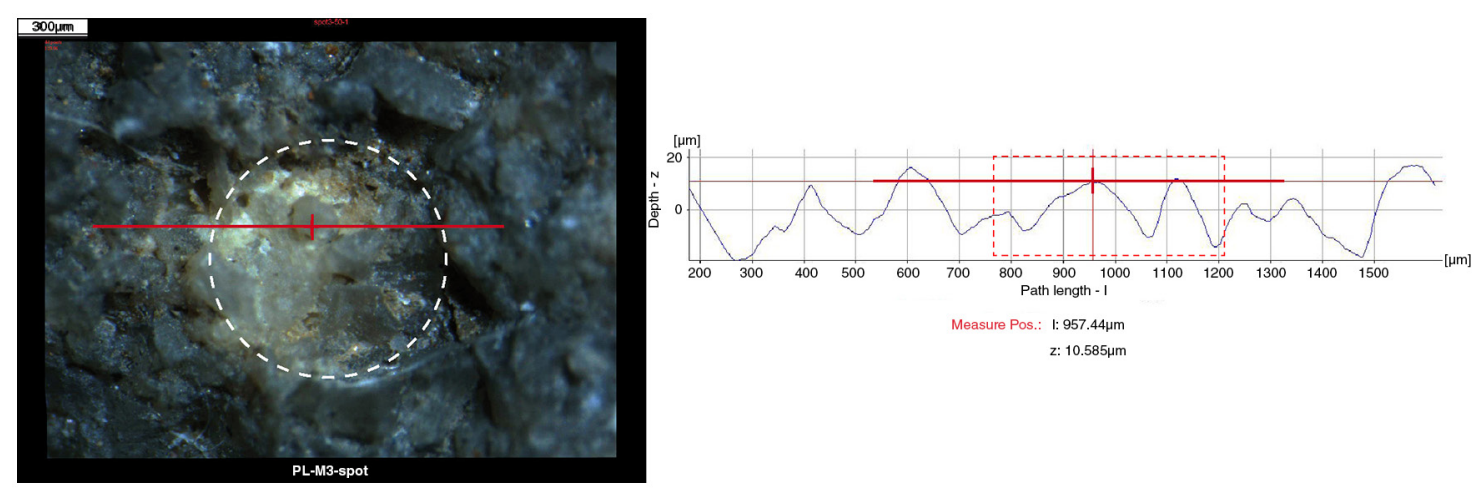

FIgURE 3. Regular spot shape with punctual material loss (left). Primary profile of analysed area with spot area in dotted rectangle: similar peaks and valleys in treated area and in the untreated one (right). 3D stereomicroscope image. Scale $300 \mu \mathrm{m}$.

TABLE 2. Surface tests parameters and results

\begin{tabular}{|c|c|c|c|c|c|c|c|c|}
\hline \multirow[b]{2}{*}{ Surface test } & \multicolumn{4}{|c|}{ Constant parameters } & \multicolumn{4}{|c|}{ Variable parameters } \\
\hline & $\begin{array}{c}\text { Energy } \\
(\mathrm{mJ})\end{array}$ & $\begin{array}{l}\text { Spot } \\
\left(\mathrm{cm}^{2}\right)\end{array}$ & $\begin{array}{l}\text { Fluence } \\
\left(\mathrm{J} / \mathrm{cm}^{2}\right)\end{array}$ & $\begin{array}{l}\text { Area } \\
\left(\mathrm{cm}^{2}\right)\end{array}$ & $\begin{array}{l}\text { Repetition } \\
\text { rate }(\mathrm{Hz})\end{array}$ & $\begin{array}{c}\text { Time } \\
\text { (s) }\end{array}$ & $\begin{array}{c}\mathbf{E}_{\text {avg }} \\
\operatorname{spot}(\mathbf{J})\end{array}$ & Results \\
\hline PLS1-M1 & 10 & 0.0113 & 0.8849 & 0.27 & 5 & 17 & 0.0356 & $\mathrm{D}$ \\
\hline PLS1-M2 & & & & & 10 & 11 & 0.0460 & ND \\
\hline PLS1-M3 & & & & & 50 & 6 & 0.1256 & ND \\
\hline PLS1-M4 & & & & & 100 & 6 & 0.2511 & ND \\
\hline PLS1-M5 & & & & & 150 & 5 & 0.3139 & ND \\
\hline PLS1-M6 & & & & & 200 & 7 & 0.5859 & D \\
\hline
\end{tabular}

Legend: (ND) no damage, (D) material loss. 
the higher the pulse repetition rate, the more the average of pulses per spot increases because restorer is unable to move the hand-held device at the rate which the laser emits, considered by some authors a waste of energy (27, 32); and thus, the higher the repetition rate, the higher average of total energy per spot (Table 2). Repetition rate supposes an overlapping of pulses during spot manual movement especially with high repetition rate, increasing the possibility of substrate temperature rising and thus potential damage.

Analysing surfaces by macrophotography, portable microscope and stereomicroscope, punctual spot irradiation or beam movement marks on the treated surface cannot be distinguished. Dynamic parameter of spot movement seems to unify cleaning because the restorer adapts it by immediate visual assessment, reducing laser beam/substrate interaction. However, some material loss in sandstone binding phases and a slightly dark shade on some specks are observed in PLS1-M1 (at $5 \mathrm{~Hz}$ ) and PLS1-M6 (at $200 \mathrm{~Hz}$ ) in comparison with other trials (Figure 4).

Area roughness analysis indicates no significant difference in any test (Figure 5). Sa and Sq have similar values: PLS1-M1, PLS1-M2 and PLS1-M3 are barely higher than soiled surface $( \pm 0.5 \mu \mathrm{m})$, PLS1-M4 and PLS1-M6 increase slightly more $( \pm 1.5 \mu \mathrm{m}$ from average of lower values), and PLS1-M5 has the higher increase $( \pm 4 \mu \mathrm{m})$. S10z reflects similar behaviour but, as well as the same surface tests, PLS1-M1 value increase too. Results indicate some slight deviations with texture characteristics of soiled surface and thus suggest a certain degree of cleaning (or damage): the higher the values, the cleaner (or more damaged) the surface might be.

Taking into account volume parameters it can be ascertained that Vmp and Vvv are similar in all surface tests suggesting that peaks and valleys remain relatively unchanged. Analysing the core volume, both $\mathrm{Vmc}$ and $\mathrm{Vvc}$ have a similar behaviour to $\mathrm{Sa}$ and $\mathrm{Sq}$. Nevertheless Vvc/Vmc ratio seems to describe more likely surface behaviour indicating that PLS1-M1 and PLS1-M6 have a higher volume void, suggesting a higher degree of cleaning (or damage).

Analysing surface tests colour, cleaning leads to colour changes in all surface tests in comparison to soiled surfaces. However, although the increase in lightness $\left(\Delta \mathrm{L}^{*}\right)$ is noticeable with the naked eye, it is more evident in PLSM-2, PLSM-3, PLSM-4 and PLSM-5. Changes in $\Delta \mathrm{a}^{*}$ and $\Delta \mathrm{b}^{*}$ are limited but more significant in the same surface tests. The total colour change $\left(\Delta E^{*}\right)$ between cleaned and soiled surfaces indicate that PLSM-1 and PLSM-6 are the least cleaned surface tests (Figure 6).

Area roughness (mainly volume parameters) and colour analysis show that results are similar to those obtained by optical techniques: PLSM-1 and PLSM-6 have the highest volume void (related to some material loss) and are the least cleaned surface tests.
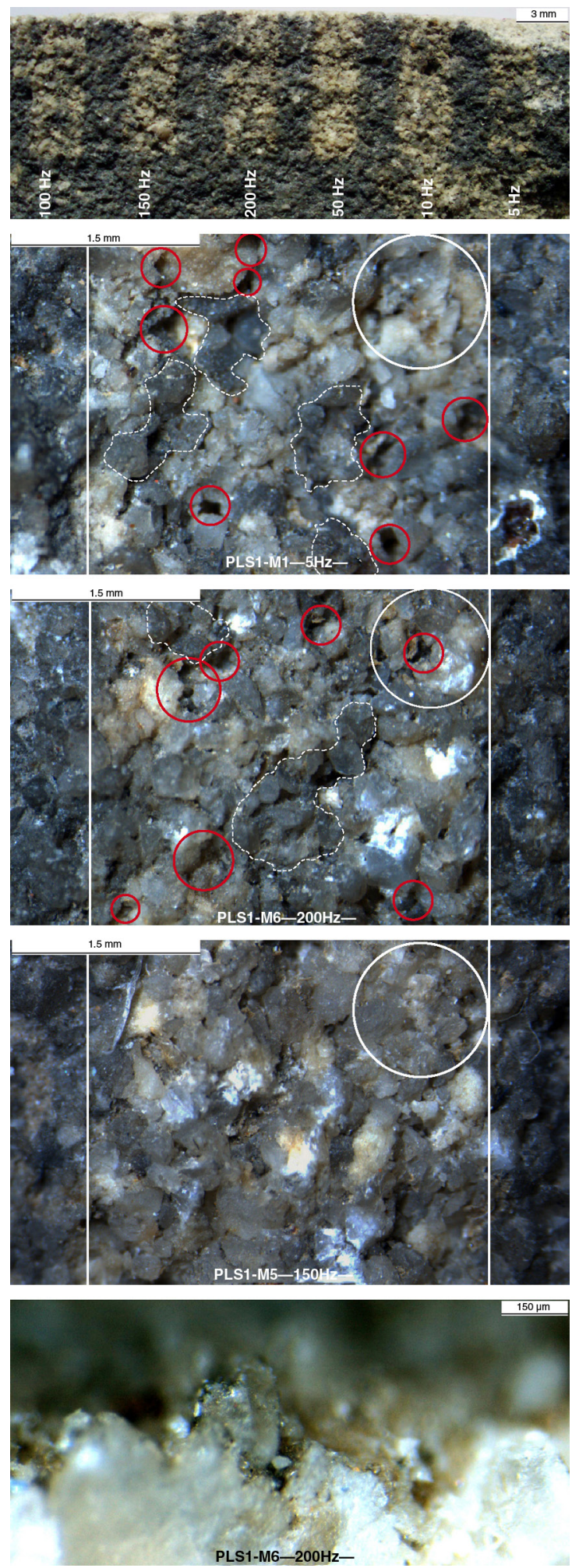

FIGURE 4. Macrophotography of surface tests at different repetition rate. Scale $3 \mathrm{~mm}$ (top). Surface tests (inset with theoretical spot area): punctual dark shading in dotted area and material loss in red circle. 3D stereomicroscope image.

Scale $1.5 \mathrm{~mm}$ (centre). Cross section: punctual dark shading linked to crust residues after cleaning. 3D stereomicroscope image. Scale $150 \mu \mathrm{m}$ (bottom). 

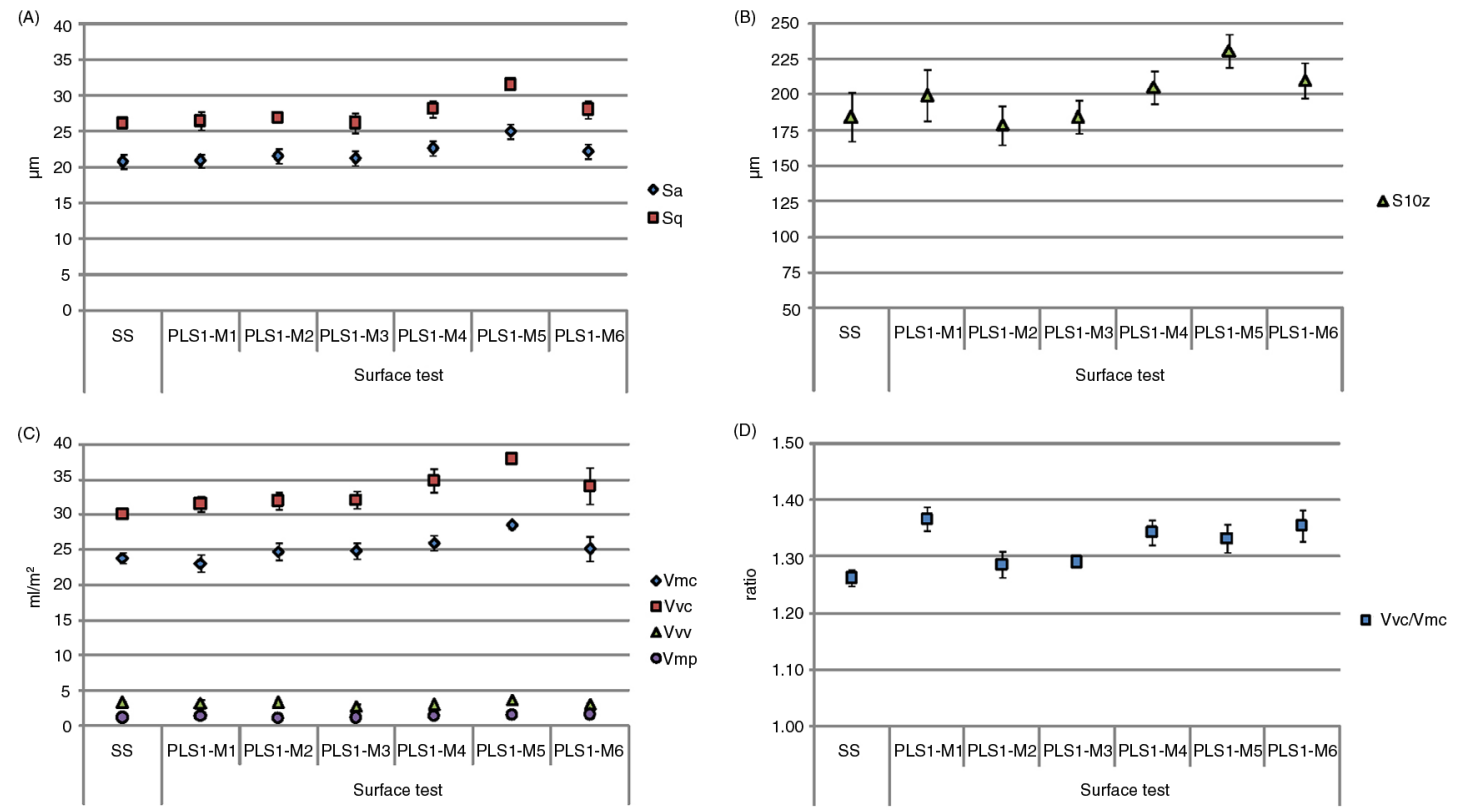

FIGURE 5. Area roughness analysis of soiled surface - SS - and of surface tests: $\mathrm{Sa}-\mathrm{Sq}(\mathrm{A})$ and $\mathrm{S} 10 \mathrm{z}(\mathrm{B})$ parameters, volume parameters (C) and ratio $\mathrm{Vvc} / \mathrm{Vmc}(\mathrm{D})$.
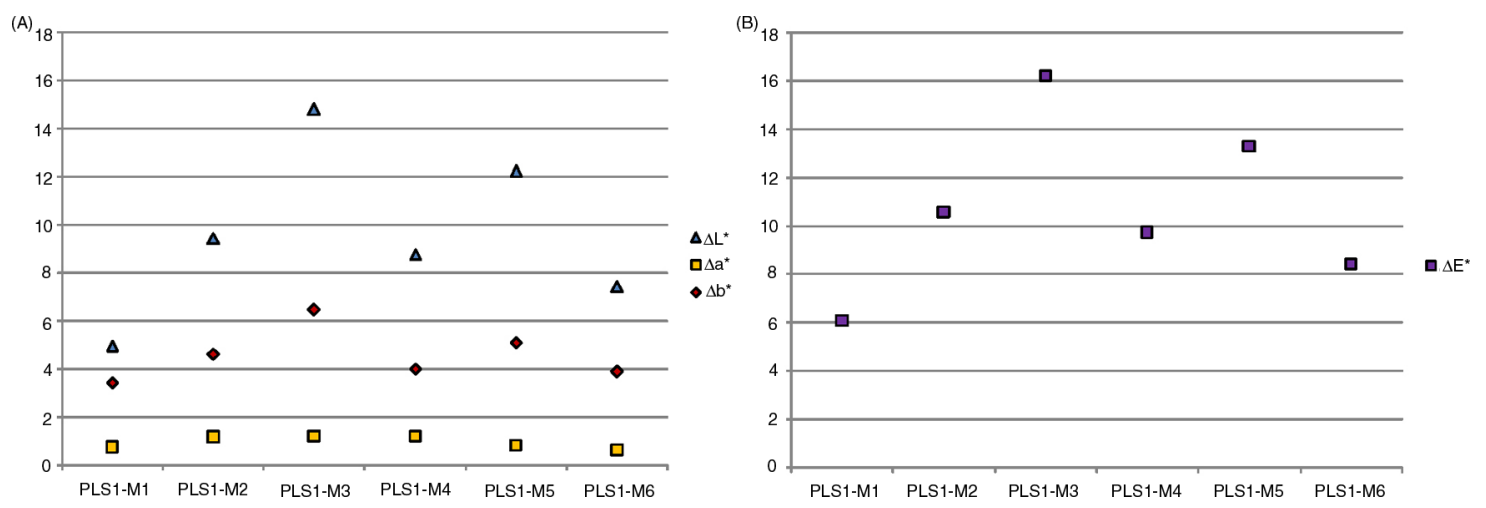

Figure 6. Colour analysis of surface tests: $\Delta \mathrm{L}^{*}, \Delta \mathrm{a}^{*}, \Delta \mathrm{b}^{*}$ coordinates (A) and $\Delta \mathrm{E}^{*}(\mathrm{~B})$.

Material loss, as in spot tests, is usually related to sandstone binding phases. According to most references on siliceous sandstones $(3,8,30-34)$, its origin could be found mainly in shock waves and photothermal and photomechanical effects affecting the most sensitive minerals.

Some studies have documented darkening of quarry and monument specimens of siliceous sandstones (8) and in samples soiled deliberately in laboratory (30) using a $1064 \mathrm{~nm}$ laser but, in this case, dark shading does not seem to be linked. Although material has a complex mineralogical composition, if colour change was related to wavelength it should also be detected in other surface tests and not only in the two mentioned.

To explain this dark shading significant differences in bonding between crust/substrate are also discarded due to the reduced size of total test area. Although it is complex to determine, this occasional dark shading seems related to restorer's laser beam movement and its visual assessment during cleaning which can leave some specks treated in a different way than other surface tests. Some restorers refer to a dot effect during laser cleaning (36) and some authors have reported darkening related to a non-homogenous cleaning, pointing out that the adhesion crust/substrate impedes uniform removal of soiling in some areas (17) or an uneven or partial soiling removal (18). In this case, after SEM images analysis indicating that dark shading is similar to black soiling crust, it is interpreted as an uneven crust removal (Figure 7) because, in addition, these areas are quite similar to the theoretical spot diameter. 

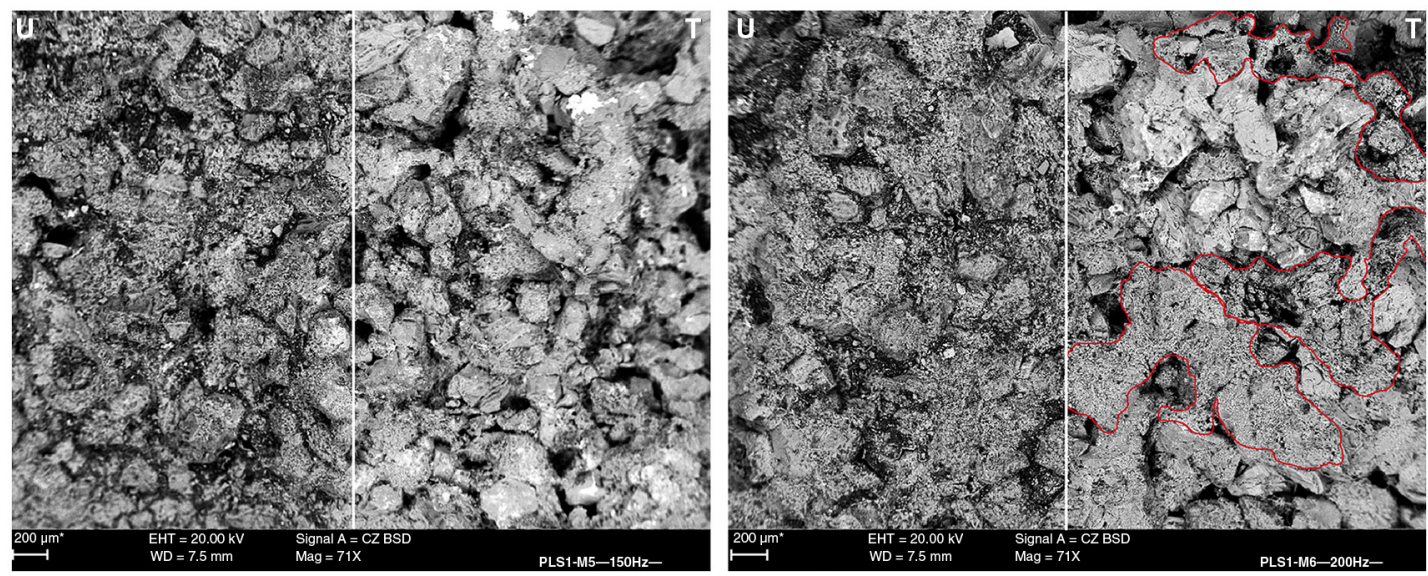

FIGURE 7. SEM-BSE image of PLS1-M5 and PLS1-M6 - (U) untreatred, (T) treatedPunctual dark shading similar to black soiling crust in red dotted area. Scale $200 \mu \mathrm{m}$.

According to the results, using the same fluence in an actual cleaning with high repetition rate equipment the restorer would be able to select the lowest averages of total energy applied per spot that have not caused damage from previous surface tests (in this case between $0.046-0.313 \mathrm{~J}$ ), selecting the cleaning level after colorimetric measurements. As a result, if some soiling residues remained on the surface due to restorer's fast beam movement, he could leave a more homogeneous surface supplying supplementary pulses at these specific points.

\section{CONCLUSIONS}

From the results, it can be observed that for operation under high pulse repetition rates the average of total energy per spot could be a useful parameter and should be attendant upon fluence for a systematic and accurate description of a cleaning intervention by the restorer. In addition to fluence, average of total energy per spot in an actual cleaning allows for taking into account the required manual laser beam movement, especially when high repetition rate equipment is used.

Prior to an actual cleaning intervention, spot analysis provides useful information about cleaning effects and potential surface damage on a specific small area. To clarify cleaning practice it is subsequently necessary to corroborate the data obtained through surface tests, including restorer's manual spot movement, to determine practical issues.

Simple techniques allowing comparative optical evaluation at different scales provide useful information for a preliminary spot and surface test analysis following the needs of restorers in an actual intervention. Direct observation and images obtained clarify preliminary interpretation because surface deposits are essentially perceived as a modification of visual parameters of what is considered a soiled or clean surface. SEM images, area roughness and colour analysis add further accurate information for cleaning assessment with data easily interpretable by the restorer. Comparative analysis with these techniques could be appropriate to control and monitor cleaning effectiveness in an actual intervention. The correlation of data obtained from each of these techniques adds significant information to the evaluation of effects on treated surface morphology.

\section{ACKNOWLEDGEMENTS}

To Dr. Salvador Borrós and María José Alcayde Palanca (GEMAT, Institut Químic de Sarrià, Universitat Ramon Llull) for facilitating the use of 3D stereomicroscope. To Núria Guasch Ferré (GRAPAC/CETEC-patrimoni, Universitat Autònoma de Barcelona) for their suggestions.

\section{REFERENCES}

1. Lazzarini, L.; Laurenzi Tabasso, M. (1986) Il restauro della pietra, CEDAM, Padova

2. Ashurst, N. (1994) Cleaning historic buildings vol. 2: Cleaning materials and processes, Donhead Publishing, London.

3. Cooper, M. (1998) Laser cleaning in conservation: An introduction, Butterworth-Heinemann, Oxford.

4. Fotakis, C.; Anglos D.; Zafiropulos V.; Georgiou S.; Tornari V. (2006) Lasers in the preservation of cultural heritage: principles and applications, Taylor \& Francis, New York.

5. Maravelaki, P.; Biscontin, G.; Polloni, R.; Cecchetti, W.; Zendri, E. (1992) Investigation on surface alteration of limestone related to cleaning processes. In Delgado Rodriguez, J.; Henriques, F.; Jeremias, F.T. (eds.). Proceedings of the $7^{\text {th }}$ International Congress on Deteriorarion and Conservation of Stone, Laboratório Nacional de Engenharia Civil, Lisbon, 1093-2002

6. Cooper, M.; Emmony, D.C.; Larson, J.H. (1992) A comparative study of the laser cleaning of limestones. In Delgado Rodriguez, J.; Henriques, F.; Jeremias, F.T. (eds.). Proceedings of the $7^{\text {th }}$ International Congress on Deteriorarion and Conservation of Stone, Laboratorio Nacional de Engenharia Civil, Lisbon, 1307-1315.

7. Sabatini, G.; Giamello, M.; Pini, R.; Siano, S.; Salimbeni, R. (2000) Laser cleaning methodologies for stone façades and monuments: laboratory analyses on lithotypes of 
Siena architecture. J. Cult. Herit. 1 [1], s9-s19. http:// dx.doi.org/10.1016/S1296-2074(00)00144-8.

8. Siano, S.; Fabiani, F.; Pini, R.; Salimbeni, R.; Giamello, M.; Sabatini, G. (2000) Determination of damage thresholds to prevent side effects in laser cleaning of pliocene sandstone of Siena. J. Cult. Herit. 1 [1], s47-s53. http://dx.doi.org/ 10.1016/S1296-2074(00)00194-1.

9. Lanterna, G.; Matteini, M. (2000) Laser cleaning of stone artifacts: a substitute or alternative method?. J. Cult. Herit. 1 [1], s29-s35. http://dx.doi.org/10.1016/S1296-2074(00)00136-9.

10. Salimbeni, R.; Pini, R.; Siano, S.; Calcagno, G. (2000) Assessment of the state of conservation of stone artworks after laser cleaning: comparison with conventional cleaning results on a two-decade follow up. J. Cult. Herit. 1 [4], 385-391. http://dx.doi.org/10.1016/S1296-2074(00)01094-3.

11. Moropoulou, A.; Tsiourva, Th.; Bisbikou, K.; Tsantila, V.; Biscontin, G.; Longega, G.; Groggia, M.; Dalaklis, E.; Petritaki, A. (2002) Evaluation of cleaning procedures on the facades of the Bank of Greece historical building in the center of Athens. Build. Environ. 37 [7], 753-760. http:// dx.doi.org/10.1016/S0360-1323(01)00058-0.

12. Gaspar, P.; Hubbard, C.; McPhail, D.; Cummings, A. (2003) A topographical assessment and comparison of conservation cleaning treatments. J. Cult. Herit. 4 [1], 294s-302s. http://dx.doi.org/10.1016/S1296-2074(02)01211-6.

13. ASTM E1857-97:2004. Standard guide for selection of cleaning techniques for masonry, concrete and stucco surfaces.

14. UNE 41806-4:2009 IN. Conservación de edificios. Limpieza de elementos constructivos. Parte 4: Técnicas de limpieza con láser.

15. BS 8221-1:2012, Code of practice for cleaning and surface repair of buildings, Part 1: Cleaning of natural stone, brick, terracotta and concrete.

16. UNI 11187:2006. Beni Culturali. Materiali lapidei naturali ed artificiali. Pulitura con tecnologia laser.

17. Pouli, P.; Fotakis, C.; Hermosin, B.; Saiz-Jimenez, C.; Domingo, C.; Oujja, M.; Castillejo, M. (2008) The laserinduced discoloration of stonework; a comparative study on its origins and remedies. Spectrochim. Acta A. 71 [3], 932-945, http://dx.doi.org/10.1016/j.saa.2008.02.031.

18. Pouli, P.; Oujja, M.; Castillejo, M. (2012) Practical issues in laser cleaning of stone and painted artefacts: optimisation procedures and side effects. Appl. Phys. A. 106 [2], 447-464, http://dx.doi.org/10.1007/s00339-011-6696-2.

19. Gómez-Heras, M.; Alvarez de Buergo, M.; Rebollar, E.; Oujja, M.; Castillejo, M.; Fort, R. (2003) Laser removal of water repellent treatments on limestone. Appl. Surf. Sci. 219 [3-4], 290-299, http://dx.doi.org/10.1016/S0169-4332(03)00701-3.

20. Gómez-Gras, D.; Parcerisa, D.; Calvet, F.; Porta, J.; Solé de Porta, J.N.; Civís, J. (2001) Statigraphy and petrology of the Miocene Montjuic delta (Barcelona, Spain). Acta Geológica Hispánica, 36, 115-136.

21. Esbert, R.M.; Ordaz, J.; Alonso, F.J. (1999) Anàlisi i pautes d'actuacions en els elements de pedra de les façanes de l'Eixample de Barcelona, Pro-Eixample, Barcelona.

22. Iglesias, M.; Prada, J.L.; Guasch, N. (2008) Technique for cleaning Tarragona Miocene age dolomitizied silty limestone, altered by urban pollution. Mater. Construc. 58 [289-290], 247-262. http://dx.doi.org/10.3989/mc.2008.v58.i289-290.87.

23. Sáiz, B.; Iglesias, M. (2008) A study of laser cleaning parameters using a portable system on a gargoyle of the Torres de Serranos in Valencia (Spain). In Castillejo, M.; Moreno, P.; Oujja, M.; Radvan, R.; Ruiz, J. (eds.). Lasers in the
Conservation of Artworks VII, CRC Press-Taylor \& Francis Group, London, 183-188.

24. Sáiz Mauleón, B. (2003) La limpieza de materiales pétreos con la técnica láser. Determinación de los parámetros de limpieza láser para una gárgola de las Torres de Serranos de Valencia, Universidad de Valencia, Spain, (2003). PhD thesis.

25. Dajnowski, A. (2008) Laser cleaning of the Nickerson Mansion: The first building in the US entirely cleaned using laser ablation. In Castillejo, M.; Moreno, P.; Oujja, M.; Radvan, R., Ruiz, J. (eds.). Lasers in the Conservation of Artworks VII, CRC Press-Taylor \& Francis Group, London, 209-214.

26. Graue, B.; Brinkmann S.; Verbeek, C. (2011) PROTOCON TT 49: laser cleaning of ancient Egyptian wall paintings and painted stone surfaces. In Radvan, R.; Asmus, J.F.; Castillejo, M.; Pouli, P.; Nevin, A. (eds.). Lasers in the Conservation of Artworks VIII, CRC Press-Taylor \& Francis Group, London, 53-58.

27. Hildenhagen, J.; Dickmann, K. (2011) Comparative studies: cleaning results of short pulsed Nd:YAG vs. fibre. In Radvan, R.; Asmus, J.F.; Castillejo, M.; Pouli, P.; Nevin, A. (eds.). Lasers in the Conservation of Artworks VIII, CRC PressTaylor \& Francis Group, London, 119-122.

28. Vázquez-Calvo, C.; Álvarez de Buergo, M.; Fort, R.; Varas-Muriel, M.J. (2012) The measurement of surface roughness to determine the suitability of different methods for stone cleaning. J. Geophys. Eng. 9 [4], S108-S117. http:// dx.doi.org/10.1088/1742-2132/9/4/S108.

29. ISO 25178:2012. Geometrical product specification (GPS) - surface texture: areal - part 2: terms, definitions and surface texture parameters.

30. Svobodová, J.; Slovák, M.; Prikryl, R; Siegl, P (2003) Effect of low and high fluence on experimentally laser-cleaned sandstone and marlstone tablets in dry and wet conditions. J. Cult. Herit. 4 [1], 44-49. http://dx.doi.org/10.1016/ S1296-2074(02)01226-8.

31. Klein, S.; Stratoudaki, T.; Marakis, Y.; Zafiropulos, V.; Dickmann, K. (2000) Comparative study of different wavelengths from IR to UV applied to clean sandstone. Appl. Surf. Sci. 157 [1-2], 1-6. http://dx.doi.org/10.1016/ S0169-4332(99)00561-9.

32. Labouré, M.; Bromblet, P.; Orial, G.; Wiedemann, G.; Simon-Boisson, C. (2000) Assessment of laser cleaning rate on limestones and sandstones. J. Cult. Herit. 1 [1], s21-s27. http://dx.doi.org/10.1016/S1296-2074(00)00195-3.

33. Rodríguez-Navarro, C.; Elert, K.; Sebastián, E.; Esbert, R.M.; Grossi, C.M.; Rojo, A.; Alonso, F.J.; Montoto, M.; Ordaz, J. (2003) Laser cleaning of stone materials: an overview of current research. Reviews in Conservation. 4, 65-82.

34. Marakis, G.; Maravelaki, P.; Zafiropulos, V., Klein, S.; Hildenhagen, J.; Dickmann, K. (2000) Investigations on cleaning of black crusted sandstone using different UV-pulsed lasers. J. Cult. Herit. 1 [1], s61-s64. http://dx.doi.org/10.1016/ S1296-2074(00)00193-X.

35. Pozo, S.; Barreiro, P; Rivasa, T.; González, P.; Fioruccica, M.P. (2014) Effectiveness and harmful effects of removal sulphated black crust from granite using Nd:YAG nanosecond pulsed laser. Appl. Surf. Sci. 302, 309-313, http://dx.doi. org/10.1016/j.apsusc.2013.10.129.

36. Chevillot, C.; Watelet, S. (2003) Laser cleaning in French museums: towards instating a methodology. J. Cult. Herit. 4 [1], 27-32, http://dx.doi.org/10.1016/S1296-2074(02)01223-2. 